\title{
MEAN-FLOW-STRESS ANALYSIS OF LABORATORY HOT-ROLLED S1100QL STEEL WITH MINOR Nb ADDITION
}

\author{
MFS ANALIZA LABORATORIJSKO VROČE VALJANEGA JEKLA \\ S1100QL Z MANJŠIM DELEŽEM Nb
}

\author{
Jan Foder ${ }^{1}$, Grega Klančnik ${ }^{1 *}$, Jaka Burja ${ }^{2}$, Samo Kokalj ${ }^{1}$, Boštjan Bradaškja ${ }^{1}$ \\ ${ }^{1}$ RCJ d.o.o., Cesta Franceta Prešerna 61, 4270 Jesenice, Slovenia \\ Institute of Metals and Technology, Lepi pot 11, 1000 Ljubljana, Slovenia \\ Prejem rokopisa - received: 2020-07-06; sprejem za objavo - accepted for publication: 2020-10-05
}

doi:10.17222/mit.2020.125

\begin{abstract}
Laboratory hot-rolling of ultra-high-strength martensitic steel S1100QL was carried out by measuring the material resistance during hot-rolling using rolling force measurements. A simplified approach was used to calculate the mean flow stress as an indirect method to analyse the material's response during hot rolling. It was shown that the method gives satisfactory results, regarding the rough detection of different temperature-deformation regions like crossing the region of considerable solute drag and precipitation hardening, known as the non-recrystallization region. The transition from the recrystallization region, where softening mainly by static or meta dynamic recrystallization is replaced with a non-recrystallization region having austenite pancaking, is clearly distinguishable for given rolling parameters and final strip thickness. The grain size distribution of the S1100QL was also evaluated from the as-cast state to the heat-treated condition.

Keywords: S1100QL, micro-alloying, hot-rolling, CALPHAD
\end{abstract}

Izvedeno je bilo laboratorijsko vroče valjanje ultra-visoko-trdnostnega martenzitnega jekla S1100QL z analizo materialnega odziva na preoblikovanje preko meritev sil valjanja. Izračunana je bila srednja napetost tečenja (MFS), preko katere lahko indirektno analiziramo odziv materiala med vročim valjanjem. Dokazali smo, da z uporabo MFS analize dobimo zadovoljive rezultate, vezano na detekcijo različnih temperaturno-deformacijskih področij, kot je območje kjer raztopljeni elementi povzročajo dodaten upor in območje izločevalnega utrjevanja, znano kot območje ne-rekristalizacije. Za dane parametre valjanja in končno debelino traku je jasno viden prehod iz področja, kjer poteka mehčanje s statično ali metadinamično rekristalizacijo, $v$ področje kjer je ta omejena oziroma ne poteka, s prehodom avstenitnega kristalnega zrna iz ekviaksialne v palačinkasto obliko. Določena je bila tudi razporeditev velikosti prvotnih avstenitnih kristalnih zrn od litega do končnega toplotno obdelanega stanja jekla S1100QL.

Ključne besede: S1100QL, mikrolegiranje, vroče valjanje, CALPHAD

\section{INTRODUCTION}

Ultra-high-strength steels (UHSS) and high-strength low-alloyed steels (HSLA) have a high strength-toweight ratio and are often used in the automotive industry, construction, mining and elsewhere. HSLA and UHSS are both used for demanding welded structures, with the emphasis on achieving a high yield strength and ductility. Various strengthening mechanisms like grain refinement, the formation of deformation substructures (dislocations), solid-solution strengthening and precipitation strengthening are used to achieve the ultra-high strength. The strengthening mechanism depends on the given alloy composition and the production route. In this paper the influence of hot rolling is emphasized. Nevertheless, a combination of secondary metallurgy and casting practice with final heat treatment is also of great importance for consistent production quality. Therefore, similar chemical compositions and different technological routes, such as different rolling schedules, will undoubtedly lead to different material properties, which

*Corresponding author's e-mail:

klancnik.grega@gmail.com (Grega Klančnik) will also be measured in the final heat-treated condition. Unfortunately, all strengthening mechanisms, with the exception of grain refinement, have a negative effect on the impact toughness and ductility. Hot rolling is therefore a key step in the production of UHSS and HSLA with superior properties.

\section{$1.1 S 1100 Q L$}

Niobium microalloyed steel S1100QL (Mat.No 1.8942 ) is a non-standardized fine-grained, fully martensitic UHSS. S1100QL must meet the minimum yield strength of $1100 \mathrm{MPa}$ (with a tensile strength between $1200 \mathrm{MPa}$ and $1500 \mathrm{MPa}$ ) and a Charpy impact toughness of at least $27 \mathrm{~J}$ transverse and $30 \mathrm{~J}$ longitudinal to the rolling direction at $-40{ }^{\circ} \mathrm{C} .{ }^{1}$ Grain size control is achieved with proper hot-rolling and selected reheating temperatures. Low-temperature tempering is performed after water quenching to maintain adequate yield strength and increase in ductility. This paper focuses on achieving the minimum yield strength of $1100 \mathrm{MPa}$ by quenching and low-temperature tempering. In the case of on-line heat treatment, austenite conditioning prior to quenching must be considered. Irrespective of the type of 
heat treatment, it is recognized that the martensite block and packet size tend to scale linearly with the parent austenite grain size (PAGS), affecting the size of the high-angle substructures $\left(>15^{\circ}\right.$ misorientation $){ }^{2}$ This is important if the packet size is considered as the "effective grain size" in relation to the yield strength and toughness of the lath martensite. ${ }^{3}$ The effective grain size and distribution in combination with steel cleanliness, which is the result of secondary metallurgy practice, determines the functional properties such as the weldability and formability of high-strength steels, therefore an optimal rolling schedule is important and necessary. ${ }^{4,5}$ Nowadays, the advanced hot-rolling technology for HSLA and UHSS plate production is based not only on austenite grain refinement and control over the precipitation of nitrides, carbides and carbo-nitrides, but also on transformation control during cooling after hot rolling with the possibility of significantly reducing the alloying, such as reducing the expensive molybdenum, and still obtaining excellent or even improved mechanical properties. This is possible if the process of controlled hot rolling is coupled with on-line controlled cooling using accelerated cooling (ACC), ultra-fast cooling (UFC) or even direct quenching (DQ) technology. ${ }^{6}$ This promising technology of thermo-mechanical control processes (TMCP) with controlled cooling, not only to improve the strength and ductility properties for certain steel grades, but also for steel mill time and energy efficiency, still needs to be adapted for HSLA and UHSS production in the local region.

\subsection{Strip/plate rolling}

Phenomena occurring during the hot deformation (hardening, softening etc.) of steels are usually studied by hot compression, tension and torsion tests on thermo-mechanical simulators. ${ }^{7-9}$ Numerous specimens and tests are required to obtain the relevant data on the hot-deformation behaviour. The use of a laboratory rolling mill for the evaluation of the mean flow stress (MFS) is an alternative method for the investigation of the hot deformation of steels. It is particularly useful for obtaining important data during successive reductions in the hot-rolling process. In addition, basic mechanical properties such as strength and toughness, bending, etc. are obtained from the sample in a similar way to industrial strip/plate production, as larger samples are produced and tested.

The final grain size can be achieved through strainfree austenite, formed by plastic deformation. Only limited grain refinement is expected after cooling and the transformation from austenite to ferrite. This means that during conventional hot rolling and recrystallization-controlled rolling (RCR), the main deformations are carried out as part of the roughing phase. The latter with an emphasis on higher per-pass reductions. When finishing passes are introduced, they are mainly adjusted to the target dimension tolerance and flatness in relation to the selected finish rolling temperatures (FRT). A finer grain size is expected when additional deformation at lower temperatures is introduced to obtain deformed austenite grains with deformation bands and strain-induced precipitates (SIP). Combined two-stage rolling of roughing and finishing with a certain time delay between the roughing and finishing phase is called controlled rolling. ${ }^{10}$ According to Dutta et al., ${ }^{11}$ the recrystallization limit temperature (RLT) is the lowest temperature for the roughing phase to prevent the formation of a mixed microstructure by partial recrystallization. A mixed microstructure causes the scattering of the final mechanical properties. ${ }^{5,10}$ The RLT temperature can be interpreted as the non-recrystallisation temperature $T_{\mathrm{nn}}$, due to limited recrystallisation.

Based on the recrystallization behaviour, plastic deformation can be divided into three main characteristic regions (Figure 3): 5,10

- Region I - typical for deformation above the RLT, the temperature where approx. $95 \%$ recrystallization still occurs. The deformation per pass and the interpass times control the softening ratio achieved by static recrystallization (SRX) or meta dynamic recrystallization (MDRX) during rough rolling or RCR.

- Region II - is below the recrystallization stop temperature (RST), the temperature below which less than $5 \%$ recrystallization still occurs.

- Region III - is between region I and II (between RLT and RST) and should be avoided due to the limited control of recrystallization, grain growth and precipitation. It is also referred to as the partial recrystallization region (95\% to $5 \%$ of SRX).

Below the RST, where recrystallisation of less than $5 \%$ is expected, both finish rolling and hot levelling are usually carried out for controlled rolling. In some cases, due to the sufficient number of passes and associated temperature drop of the final passes, this is also done by conventional hot rolling of thin plates or strips. Softening at low temperatures can be influenced by the introduction of microalloying elements such as niobium for SIP. According to Dutta and Sellars, ${ }^{11}$ the retarding effect of niobium on austenite recrystallization is observed to a lesser extent for niobium in a solid solution and more pronounced with the SIP of $\mathrm{Nb}(\mathrm{C}, \mathrm{N})$ from the austenite matrix, which means that sufficient accumulation of the deformation for SIP can effectively stop recrystallization recognized as Region II (below the RST). It has also been recognized that RST occurs when the time for $5 \%$ recrystallization (or less) is equal to the time for $5 \%$ of precipitation of $\mathrm{Nb}(\mathrm{C}, \mathrm{N}) .{ }^{11}$ Inhibition of recrystallization is effective until the end of precipitation and loss of the effective pinning force (Zenner pinning). Austenite grains are therefore elongated (pancaked) in rolling direction if sufficient strain is accumulated and that minimum incubation time is respected for the successful SIP of $\mathrm{Nb}(\mathrm{C}, \mathrm{N})$ (see Figure 1c). ${ }^{12}$ It is also recognized that deformation accelerates precipitation, providing prefer- 
Table 1: Chemical composition of S1100QL billet, in mass fractions, (w/\%)

\begin{tabular}{|c|c|c|c|c|c|c|c|c|c|c|c|}
\hline $\mathrm{C}$ & $\mathrm{Si}$ & $\mathrm{Mn}$ & $\mathrm{Cr}$ & $\mathrm{Ni}$ & $\mathrm{Mo}$ & $\mathrm{Al}$ & $\mathrm{Ti}$ & $\mathrm{Nb}$ & $\mathrm{B}$ & $\mathrm{N}$ & $\mathrm{Fe}$ \\
\hline 0.18 & 0.23 & 0.87 & 0.52 & 1.3 & 0.41 & 0.06 & 0.013 & 0.014 & 0.0011 & 0.0031 & bal. \\
\hline
\end{tabular}

ential sites for the nucleation and precipitation of $\mathrm{Nb}(\mathrm{C}, \mathrm{N})$ at lower supersaturation, as in the case of the undeformed austenite ${ }^{11}$ and with that expected change in flow stress behaviour $\sigma$ (sometimes written as $k_{\mathrm{f}}$ ), as it is influenced by the introduction of the dislocation density variation, $\rho$, inside the grains: ${ }^{11,13}$

$$
\sigma=\alpha G b \sqrt{\rho}
$$

Where $\alpha$ is a constant, $G$ is the shear modulus and $b$ is the Burgers vector. The dislocation density is not so trivial to measure, ${ }^{14}$ so instead of observing metallurgical phenomena associated with the change in dislocation density, a recognized change of grain-boundary migration due to SIP is possible with various methods, but also by measuring the change in the average flow stress. ${ }^{15}$

\subsection{Alloy design}

Alloy design is crucial for the rolling schedule design and final microstructure that is achieved after heat treatment. The chemical composition of S1100QL with minor niobium and titanium additions is summarised in Table 1.

In the case of niobium and titanium carbo-nitride forming, they act as a retarding force on grain-boundary migration. This is also important for limiting the grain growth during cooling. In addition to Zenner pinning with rather moderate niobium and titanium contents, grain-boundary mobility can be influenced by the solute drag of niobium, titanium and also molybdenum. ${ }^{2,16}$ Titanium and niobium additions are minor, which excludes the possibility of coarse nitride and carbonitride formation already from the molten steel, see Figure $\mathbf{1}$ a and Figure 4. ${ }^{17}$

Niobium has an important effect on RST and RLT, either in solution or even more so as strain-induced $\mathrm{Nb}(\mathrm{C}, \mathrm{N})$ precipitates. ${ }^{11,15-21}$ As mentioned above, niobium in solid solution segregates to austenite grain boundaries, which causes drag and thus retards the recrystallization by the solute-drag effect. ${ }^{16,18} \mathrm{Nb}(\mathrm{C}, \mathrm{N})$ precipitates are more effective in retarding recrystallization. They nucleate first at the austenite grain boundaries (RLT) and later at the dislocations with matrix precipitation (RST), pinning them and thus retard recrystallization by preventing grain-boundary migration. ${ }^{19-21}$

The non-recrystallization temperature $\left(T_{\mathrm{nr}}\right)$ is normally used to determine the critical temperature at which strain accumulation occurs during hot rolling. $T_{\mathrm{nr}}$ is normally assumed to be similar or close to the RLT, although the exact position depends on other variables such as strain, strain rate, experimental method used, etc.
This means that $T_{\text {nr }}$ can be identified between RLT and RST, depending on the experimental method and the given parameters. According to literature ${ }^{5,10}$, the MFS range for Region III in standard HSLA grades during hot rolling with typical per pass reductions and strain rates for thin plate or strip rolling is between $150 \mathrm{MPa}$ and $200 \mathrm{MPa}$. To correlate the measured MFS change in correspondence to $T_{\mathrm{nr}}$, we have used the widely accepted Boratto's equation for HSLA grades: ${ }^{22}$

$$
\begin{aligned}
& T_{\mathrm{nr}}=887+464 \mathrm{C}+6445 \mathrm{Nb}-644 \sqrt{\mathrm{Nb}}+732 \mathrm{~V}-230 \\
& \sqrt{\mathrm{V}}+890 \mathrm{Ti}+363 \mathrm{Al}-357 \mathrm{Si}
\end{aligned}
$$

where all the elements are given in mass percent.

\subsection{Rolling load model}

According to $\mathrm{Sims}^{23}$, the calculation of rolling force $F$ can be easily calculated by:

$$
F=k_{\mathrm{fm}} b l_{\mathrm{d}} Q_{\mathrm{f}}
$$

where $b$ is the plate width, $l_{\mathrm{d}}$ is the horizontal projection length of the contact arc between the squashed roller and plate, $Q_{\mathrm{f}}$ is the geometric factor and $k_{\mathrm{fm}}$ is the mean metal deformation resistance or the mean value of constrained yield stress in the roll gap. It is also possible to introduce the effect of the rolling force by tensile stress (i.e., Steckel). ${ }^{24}$ It is important that the equations can also be used for strain-hardening materials, not only for ideal plastic-rigid material. If plane deformation is assumed, some precautions must be taken if the width/thickness ratio per pass is less than 5. In this paper an additional simplification has been made by setting $Q_{\mathrm{f}}$ to unity.

\section{EXPERIMENTAL PART}

The experimental S1100QL steel was produced in a vacuum induction furnace and cast as a $12-\mathrm{kg}$ ingot $(80 \times 80) \mathrm{mm}^{2}$. The ingot was heated to $1150{ }^{\circ} \mathrm{C}$ and soaked for $2 \mathrm{~h}$ before hot forging into a $(60 \times 60) \mathrm{mm}^{2}$ billet. The billet was cut into two parts. Individual billets intended for strip hot rolling were then reheated to $1200{ }^{\circ} \mathrm{C}$ for $30 \mathrm{~min}$ (a total $2.5 \mathrm{~h}$ for temperature homogeneity) to ensure that the niobium was completely in the austenite solution in order to achieve an effective and uniform recrystallization retardation by solute drag or SIP during hot rolling. The solubility temperature for $\mathrm{Nb}(\mathrm{C}, \mathrm{N})$ was determined to be $1122{ }^{\circ} \mathrm{C}$ using the Irvine ${ }^{25}$ equation. An additional infrared camera Optris PI $1 \mathrm{ML}$ with a working temperature range between $450{ }^{\circ} \mathrm{C}$ and $1800{ }^{\circ} \mathrm{C}$ was used to pre-define the temperature distribution measurement before and during rolling at interpass times. The laboratory billet was then re- 
heated as described above and hot rolled in a predefined 11 passes to a final thickness of $12 \mathrm{~mm}$, using a single stand mill with subsequent continuous air-cooling. The soaking temperature and the number of passes with the specified per-pass reduction made it possible to achieve a low-temperature finish. Hot rolling was performed without interruption or time delay between the roughing and finishing to observe the MFS behaviour in the region of the RLT and/or RST (defined as $T_{\mathrm{nr}}$ in this paper) for the given chemical composition and related rolling parameters. The rolling loads were continuously measured for indirect MFS evaluation by stress measurements on the rolling mill. The last step in the production process was a laboratory heat treatment by re-austenitization of the samples in a temperature-controlled furnace using additional thermocouples (Type-K) for the samples' austenitization control. Thus, after austenitization at $900{ }^{\circ} \mathrm{C}$ and a holding time of $20 \mathrm{~min}$, the steel was first water quenched, followed by low-temperature tempering at $200{ }^{\circ} \mathrm{C}$ and a holding time of $60 \mathrm{~min}$.

The general chemical composition was determined by optical emission spectroscopy (OES), ARL MA-310. Carbon and sulphur were determined by the combustion method using a LECO CS-600 and nitrogen using a LECO TC-500, Table 1. The base composition also corresponds to other grades with a lower yield strength according to standardized steel qualities defined in reference ${ }^{26}$.
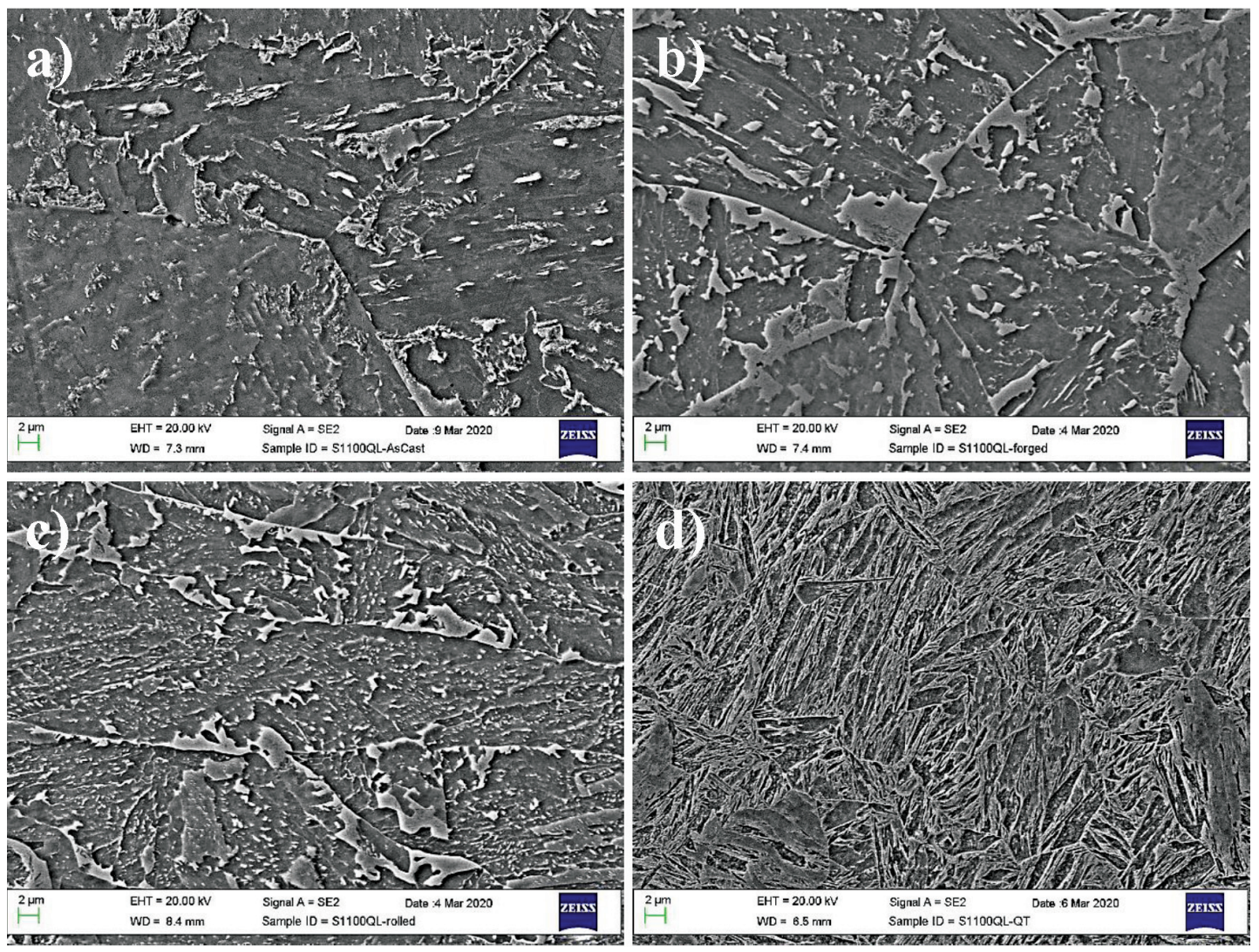

Figure 1: Secondary electron image of microstructure of: a) as-cast, b) hot-forged, c) hot-rolled and d) QT state of S1100QL steel in the as-cast, hot-forged, hot-rolled and heat-treated conditions was characterised, using scanning electron microscope with field emission gun (FE-SEM), Zeiss Supra VP55. Samples were prepared following a standard metallographic procedure of grinding, polishing and etching using 2 vol. \% Nital solution. PAGS and distribution were determined using imageJ software by analysing an average of 400 grains.

Thermodynamic prediction, using Thermo-Calc 2020a, was also conducted using TCFE7 and TCFE9 databases for the estimation of the thermodynamically stable characteristic temperatures for carbo-nitride precipitation. A simplified isopleth equilibrium $\mathrm{Fe}-\mathrm{C}$ phase diagram (Figure 4) was calculated to provide a better visual representation of the temperature dependence of the titanium- and niobium-rich precipitates with respect to the carbon variation.

To evaluate the mechanical properties in the final tempered condition, longitudinal tensile specimens were prepared and tests were carried out according to EN ISO 6892-1:2017 B60 using Zwick/Roell Z600.27 Standard V-notch specimens for the Charpy pendulum impact test were machined according to EN ISO 148-1:2016. ${ }^{28}$ Impact toughness should be higher than $27 \mathrm{~J}$ for transverse test pieces, tested at $-40{ }^{\circ} \mathrm{C}$, as specified in the standard EN 10025-6:2019 for similar HSLA grades. ${ }^{26}$ 


\section{RESULTS AND DISCUSSION}

\subsection{Temperature evolution during hot rolling}

In order to determine a semi-empirical equation for continuous cooling during the hot rolling of S1100QL, several laboratory rolled heats at the same re-heating temperature $\left(1200^{\circ} \mathrm{C}\right)$ and final thickness $(12 \mathrm{~mm})$ were required. No water de-scaling was used. Temperature evolution during the hot rolling of S1100QL can be calculated using the obtained semi-empirical equation:

$$
T=1194.6 \exp (-0.003 t)
$$

where $T$ is the rolling temperature in ${ }^{\circ} \mathrm{C}$ and $t$ is the time in seconds elapsed since the reheated billets were taken from reheating furnace. The temperature profile is shown in Table 2. From the rolling schedule, 7 roughing passes lie between $1158{ }^{\circ} \mathrm{C}$ and $971{ }^{\circ} \mathrm{C}$ followed by 4 finishing passes down to $882{ }^{\circ} \mathrm{C}$. Achieved grains size and an example of the final as-rolled microstructure after cooling from $882{ }^{\circ} \mathrm{C}$ in air is shown in Figure 1c and Figure 2 .

\subsection{Microstructure evolution}

Microstructures of as-cast, hot-forged, hot-rolled and heat-treated $(Q T)$ conditions are shown in Figure 1a to 1d, respectively. In the as-cast to hot-rolled condition, a mixed martensitic-bainitic microstructure can be observed. Martensite occurs predominantly in the segregated regions with solute enrichment. The mixed microstructure is related to relatively slow cooling rates achieved under natural cooling in air. The grain, except in the case of the as-rolled state, is equiaxial. In Figure 1c the grains are elongated or "pancaked", indicating that the final rolling temperature (FRT) corresponds to the desired low FRT. The average PAGS and the distribution of 400 grains evaluated for each condition are presented in Figure 2.

By combining the PAGS distribution for a separate process step, the average grain refinement from coarse $320 \mu \mathrm{m}$ to rather fine $18 \mu \mathrm{m}$ from as-cast to heat-treated

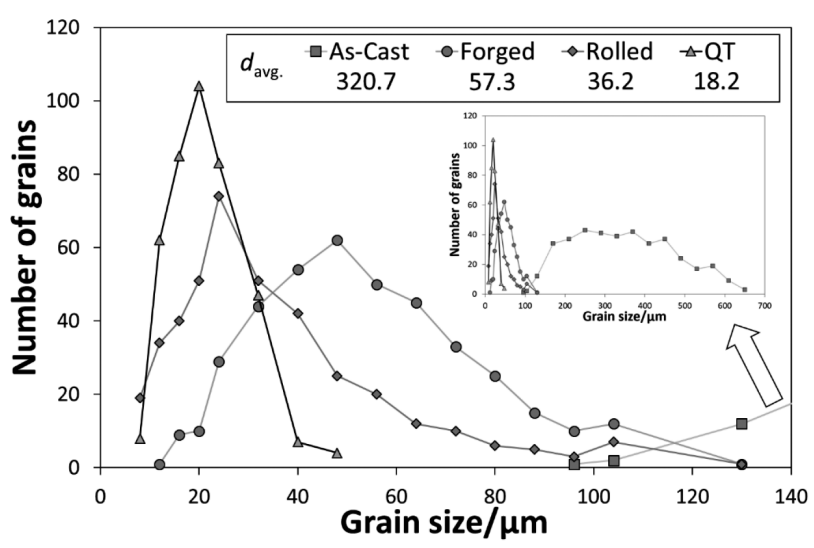

Figure 2: Prior austenite grain size distribution and average grain size for as-cast, hot-forged, hot-rolled and QT state of S1100QL steel condition is obvious. It is interesting to note that by continuous hot rolling the maximum PAGS is still quite coarse in the range of $130 \mu \mathrm{m}$. Similar results were obtained after forging with a distribution factor of $G_{\text {avg }} / G_{\max }$ $=0.28$ for rolled condition, where $G$ stands for grain size in $\mu \mathrm{m}$. Comparing the factor after re-austenitization with $G_{\text {avg }} / G_{\max }=0.38$, it becomes clear that re-austenitization of the forged-rolled condition has considerably improved the material isotropy by reducing the maximum grain size and narrowing the grain size distribution. This explains why the toughness is sometimes improved by off-line heat treatment compared to on-line, with respect to the achieved austenite conditioning before on-line quenching. Nevertheless, isotropy is also improved when preferential grain orientation is changed from pancake-shaped to equiaxed by re-austenitization.

The results of the PAGS for similar chemical compositions but different processing routes, according to literature, were from $30 \mu \mathrm{m}$ to $7 \mu \mathrm{m} .4,29$ PAGS in the hot-rolled condition is comparable to PAGS that Muckleroy et al. ${ }^{4}$ reported for the direct quenched, controlled rolled condition with a $40 \%$ reduction below $T_{\mathrm{nr}}$, for steel of similar composition. They emphasised that martensitic blocks, as discussed before, determine the effective grain size of martensitic steels and not PAGS, which is in accordance with earlier reports. ${ }^{30,31}$

\subsection{MFS analysis}

The results of the MFS analysis of laboratory hot-rolled S1100QL steel are presented in Figure 3. Rolling schedules and obtained MFS are shown in Table 2. Rolling consisted of 7 roughing passes (R1-R7), followed by 4 finishing passes (F1-F4). As can be seen in Figure 3, the MFS increases continuously up to R7 in a moderate manner, which is a result of a temperature drop and SRX. Limited secondary recrystallization or so-called grain growth appears in the case of R2, as estimated from the MFS curve. Rolling in the SRX region leads to grain refinement and improving the through-sec-

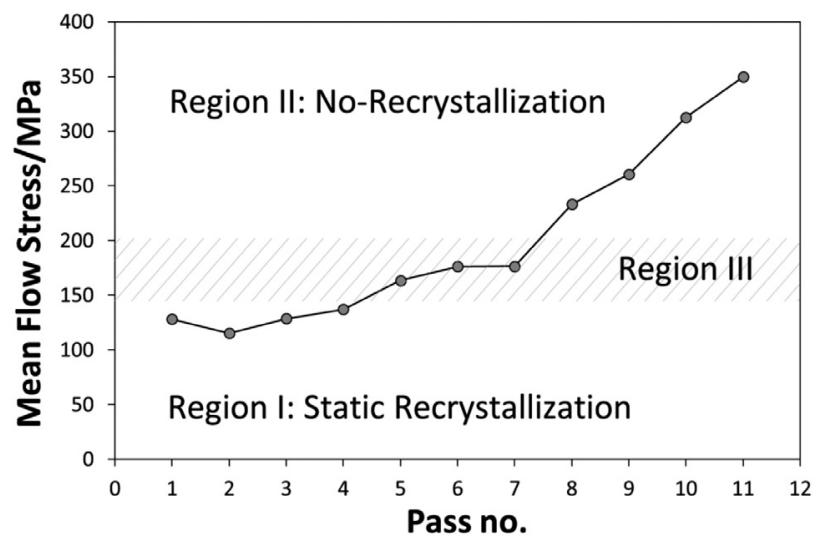

Figure 3: MFS analysis for laboratory hot rolling of S1100QL steel. Regions of different recrystallization behaviour are marked in accordance with the literature ${ }^{5,10}$ 
tion grain size distribution by successive reductions with limited grain refinement. From R7 to F4 a distinct and almost linear MFS deflection is detected. The slope change was taken as the critical temperature defined as $T_{\mathrm{nr}}$ and determined as an average between R7 to F1 due to the limited temperature raster taken by an individual test. If the limits are taken according to references ${ }^{5,10}$ the MFS curve is interpreted as R1-R4 belong to Region I, which means that SRX refines PAGS during successive passes, given that the interpass time and deformation are sufficient. Nevertheless, according to the MFS curve, R1-R6 are taken as part of the roughing phase and $\mathrm{F} 1-\mathrm{F} 4$ is the finishing phase with $\mathrm{R} 7-\mathrm{F} 1$ being the pass in the region where Type III is expected and should be avoided. This could explain the rather coarse maximum PAGS found in the as-rolled state, knowing that during precipitation of $\mathrm{Nb}(\mathrm{C}, \mathrm{N})$ niobium depletion appears in the matrix, affecting the grain-boundary mobility and enhancing the recrystallisation, thus promoting grain growth. ${ }^{32}$

If we apply temperatures calculated from equation (4), strain accumulation between R7 and F1 occurs at an average temperature of $958{ }^{\circ} \mathrm{C}$. $T_{\mathrm{nr}}$, calculated according to the Boratto's equation, is $936{ }^{\circ} \mathrm{C}$, i.e., $22{ }^{\circ} \mathrm{C}$ lower than experimentally predicted, which seems reasonable.

The results of the MFS analysis, i.e., the change in the slope after R7 to F4, can be associated with SEM micrographs of the hot-rolled condition, where elongated prior austenite grains can be seen.

In the industrial practice, MFS analysis can easily be used to optimize rolling schedules based on the material response during hot rolling, even in real-case rolling processes. Due to the different starting conditions, such as slab geometry, size and reheating time and temperature, MFS values for industrial rolling are typically lower than the values determined during laboratory rolling. Also, RLT and RST, if assumed to be $150 \mathrm{MPa}$ and $200 \mathrm{MPa}$, are considered as orientational values only, but according to the available data, this approximation still allows a fairly good estimation of where Region I and Region II are expected to be found..$^{5,10}$

Table 2: Per-pass reduction, calculated temperature, interpass time and MFS for laboratory hot rolling of S1100QL steel

\begin{tabular}{|c|c|c|c|c|}
\hline Pass no. & $\begin{array}{c}\text { Reduc- } \\
\text { tion/\% }\end{array}$ & $\begin{array}{c}\text { Tempera- } \\
\text { ture/ }{ }^{\circ} \mathrm{C}\end{array}$ & $\begin{array}{c}\text { Interpass } \\
\text { time/s }\end{array}$ & MFS/MPa \\
\hline R1 & 5,0 & 1158 & $/$ & 127 \\
\hline R2 & 11,4 & 1128 & 10 & 114 \\
\hline R3 & 13,6 & 1089 & 10 & 127 \\
\hline R4 & 15,8 & 1056 & 10 & 135 \\
\hline R5 & 17,4 & 1022 & 10 & 161 \\
\hline R6 & 16,8 & 993 & 9 & 174 \\
\hline R7 & 18,7 & 971 & 8 & 175 \\
\hline F1 & 17,1 & 945 & 8 & 231 \\
\hline F2 & 17,6 & 922 & 8 & 257 \\
\hline F3 & 14,3 & 903 & 8 & 309 \\
\hline F4 & 12,5 & 882 & 8 & 346 \\
\hline
\end{tabular}

\subsection{Thermodynamic analysis}

The predicted equilibrium phase diagram $\mathrm{Fe}-\mathrm{C}$ has been simplified by excluding boron, sulphur and phosphorous for easier visualisation. The minor addition of titanium shows no risk of primary (and coarse) TiN formation under the equilibrium condition of solidification due to the stability of nitrides below the solidus temperature (presented as Liquid, see Figure 4) for the given chemical composition. The temperature stability of TiN in the carbon region of interest is practically unchanged due to the constant nitrogen content and covers the entire temperature region for austenite soaking and multi-pass hot-rolling for grain size control, including cooling after rolling. The solidification path for S1100QL is presented with a vertical line at 0.18 mass percent carbon. The phase field stability of $\mathrm{TiN}$ is presented by the prototype FCC_A1\#3. The predicted isopleth diagram also shows temperature-carbon concentration relation of $\mathrm{Nb}(\mathrm{CN})$ precipitation based on the equilibrium thermodynamics of a multicomponent system according to the chemical composition in Table $\mathbf{1}$.

The precipitation of $\mathrm{Nb}(\mathrm{C}, \mathrm{N})$ in undeformed austenite is presented with the prototype of FCC_A1\#2. With constant niobium and nitrogen concentration and increasing carbon, the temperature for the homogeneous nucleation of $\mathrm{Nb}(\mathrm{C}, \mathrm{N})$ is increasing. This goes well with the nucleation theory, which refers to the solubility products of niobium, carbon and nitrogen in austenite. According to the prediction, the stability of $\mathrm{Nb}(\mathrm{C}, \mathrm{N})$ with homogenic precipitation starts already under $1092{ }^{\circ} \mathrm{C}$ or $1104{ }^{\circ} \mathrm{C}$ using the TCFE7 or TCFE9 database, respectively. When using a thermodynamic approach for a multicomponent system, the temperatures are somewhat lower when calculated by the reference ${ }^{25}$, which only takes into account niobium, carbon and nitrogen, see Table 3. Taking into consideration the thermo-mechanical processing and dislocation density generated for potential nucleation sites (based on precipitation kinetics and not included into the equilibrium phase stability calcula-

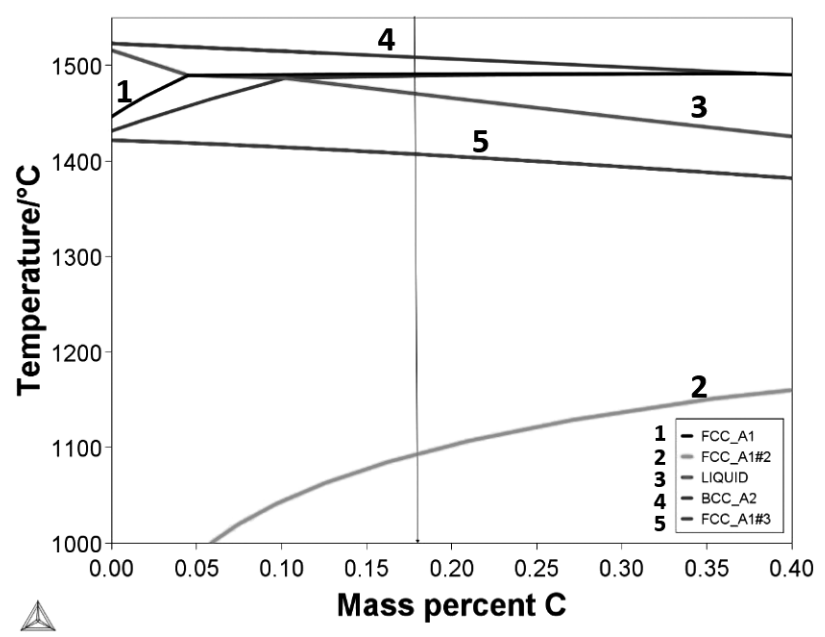

Figure 4: Isopletic equilibrium phase diagram for Fe-C for S1100QL 
tion) the total amount of precipitates at a given temperature can vary significantly due to heterogenic nucleation. In this case it is also interesting to note that the experimentally determined $T_{\mathrm{nr}}$ and the calculated one according to Boratto ${ }^{22}$ are in a rather good agreement and both are lower than the predicted homogenic nucleation start for the precipitation of niobium-rich carbo-nitrides by Thermo-Calc. The determined starts of the homogeneous (equilibrium) and experimental precipitation of $\mathrm{Nb}(\mathrm{CN})$ are gathered in Table 3. The variation between the thermodynamic calculations and the experimentally determined $T_{\mathrm{nr}}$ is expected, because the MFS change is related to the actual volume fraction and size of the precipitates formed by rolling, in order to effectively delay the recrystallisation kinetics and therefore to the rolling parameters.

Table 3: Calculated temperatures for $\mathrm{Nb}(\mathrm{C}, \mathrm{N})$ precipitation and measured $T_{\mathrm{nr}}$

\begin{tabular}{|l|c|l|}
\hline \multirow{2}{*}{ Thermo-Calc $-\mathrm{Nb}(\mathrm{C}, \mathrm{N})$ precipitation } & TCFE7 & $1092,9^{\circ} \mathrm{C}$ \\
\cline { 2 - 3 } & TCFE9 & $1104,4^{\circ} \mathrm{C}$ \\
\hline $\begin{array}{l}\mathrm{Nb}(\mathrm{C}, \mathrm{N}) \text { precipitation according to } \\
\text { Irvine }\end{array}$ & \multicolumn{2}{|c|}{$1122{ }^{\circ} \mathrm{C}$} \\
\hline$T_{\mathrm{n}}$ according to Boratto & \\
\hline MFS exp. $-T_{\mathrm{nr}}$ & $936{ }^{\circ} \mathrm{C}$ \\
\hline
\end{tabular}

\subsection{Mechanical properties}

The mechanical properties of S1100QL steel in the QT condition are shown in Table 4. The yield strength after quenching and low-temperature tempering exceeds $1100 \mathrm{MPa}$, indicating that a pre-rolling strategy with appropriate pass numbers and re-heating temperatures before hot rolling provides a good starting point for the QT process with off-line heat treatment. The ductility, expressed in $A_{5,65}$, also exceeds $10 \%$, which is required for this steel grade. Overall, the needed tensile properties are met. Charpy impact toughness $K V_{2}$ at $-40{ }^{\circ} \mathrm{C}$ is $49 \mathrm{~J}$, which is above $27 \mathrm{~J}$, prescribed in the standard. ${ }^{26}$

Table 4: Mechanical properties of S1100QL steel in QT state

\begin{tabular}{|c|c|c|c|}
\hline$R_{\mathrm{p} 0,2} / \mathrm{MPa}$ & $R_{\mathrm{m}} / \mathrm{MPa}$ & $A_{5,65} / \%$ & $K V_{2} / \mathrm{J}$ \\
\hline $\min .1100$ & $1250-1500$ & $\min .10$ & $\min .27$ \\
\hline 1160 & 1377 & 13.5 & 49 \\
\hline
\end{tabular}

\section{CONCLUSIONS}

Laboratory hot rolling of S1100QL plate was successfully performed, and MFS analysis as an indirect method shows that the position of $T_{\mathrm{nr}}$ is determined in the range of $150 \mathrm{MPa}$ and $200 \mathrm{MPa}$. This agrees well for similar grades as the limitation for RLT and RST. A relatively good agreement was obtained by comparing the measured $T_{\mathrm{nr}}$ and predicted $T_{\mathrm{nr}}$ according to Boratto, with $958{ }^{\circ} \mathrm{C}$ and $936{ }^{\circ} \mathrm{C}$, respectively. The tested rolling schedule reveals the presence of a locally coarse grain size and indicates that the optimization of rolling sched- ules is necessary for laboratory single stand rolling for the desired overall mechanical properties based on the obtained MFS curve presented in this paper. Significant improvements in the material isotropy were achieved by off-line heat treatment by reducing the maximum grain size and narrowing the grain size distribution.

The data obtained with the given parameters can be used for rolling optimization with respect to the actual rolling mill capability in terms of the maximum allowable force and torque as also for achieving the appropriate dimensional and flatness tolerance.

\section{Acknowledgments}

This research was made as a part of ČMRLJ research project co-financed by the Republic of Slovenia and the European Union under the European Regional Development Fund.

The authors also want to acknowledge Douglas Stalheim, from DGS Metallurgical Solutions, the consultant of CBMM, for overall cooperation and the experience exchange on the production of HSLA grades.

\section{REFERENCES}

${ }^{1}$ Dillinger, Dillmax 1100 Datasheet. https://www.dillinger.de, 18.5. 2020

${ }^{2} \mathrm{H}$. Mohrbacher, Property optimization in as-quenched martensitic steel by molybdenum and niobium alloying, Metals, 8 (2018) 4, doi: $10.3390 /$ met8040234

${ }^{3}$ Y. Tomita, K. Okabayashi, Effect of microstructure on strength and toughness of heat-treated low alloy structural steels, Metallurgical and Materials Transactions A, 17 (1986) 7, 1203-1209, doi:10.1007/ BF02665319

${ }^{4}$ N. C. Muckelroy, K. O. Findley, R. I. Bodnar, Microstructure and mechanical properties of direct quenched versus conventional reaustenitised and quenched plate, Journal of Materials Engineering and Performance, 22 (2013) 2, 512-522, doi:10.1007/s11665012-0251-y

${ }^{5}$ D. G. Stalheim: Recrystallization behaviours in the production of structural steels, Proc. of the $52^{\text {nd }}$ Rolling Seminar, Rio de Jeneiro, 2015, 168-177, doi:10.5151/1983-4764-26355

${ }^{6}$ Z. Wang, B. Wang, B. Wang, Y. Tian, T. Zhang, G. Yuan, Z. Liu, G. Wang, Development and application of thermo-mechanical control process involving ultra-fast cooling technology in China, ISIJ International, 59 (2019) 12, 2131-2141, doi:10.2355/isijinternational. ISIJINT-2019-041

${ }^{7}$ D. Bombač, M. Fazarinc, G. Kugler, S. Spajić, Microstructure development of Nimonic 80A superalloy during hot deformation, Materials and Geoenvironment, 55 (2008) 3, 319-328

${ }^{8}$ A. Križaj, M. Fazarinc, M. Jenko, P. Fajfar, Hot workability of $95 \mathrm{MnWCr} 5$ tool steel, Materiali in tehnologije, 45 (2011) 4 , 351-355

${ }^{9}$ P. Fajfar, B. Bradaškja, B. Pirnar, M. Fazarinc, Determination of hot workability and processing maps for AISI 904L stainless steel, Materials and Geoenvironment, 58 (2011) 4, 383-392

${ }^{10}$ D. G. Stalheim, A. Gorni, M. M. Rebellato: Basic metallurgy/processing design concepts for optimized hot strip structural steel in yield strengths from 300 to $700 \mathrm{MPa}$, Proc. of the 53rd Rolling Seminar, Rio de Jeneiro, 2016, doi:10.5151/1983-4764-27546

${ }^{11}$ B. Dutta, C. M. Sellars, Effect of composition and process variables on $\mathrm{Nb}(\mathrm{C}, \mathrm{N})$ precipitation in niobium microalloyed austenite, Materials Science and Technology, 3 (1987), 197-206, doi:10.1179/ 026708387790122846 


\section{J. FODER et al.: MEAN-FLOW-STRESS ANALYSIS OF LABORATORY HOT-ROLLED S1100QL STEEL ...}

${ }^{12}$ S. F. Medina, A. Quispe, M. Gomez, Model of precipitation kinetics induced by strain for microalloyed steels, Steel research international, 76 (2005) 7, 527-531, doi:10.1002/srin.200506049

${ }^{13}$ R. Sandström, R. Lagneborg, A model for hot working occurring by recrystallization, 23 (1975) 3, 387-398, doi:10.1016/0001-6160(75) 90132-7

${ }^{14}$ S. Takebayashi, T. Kunieda, N. Yoshinaga, K. Ushioda, S. Ogata, Comparison of the dislocation density in martensitic steels evaluated by some x-ray diffraction methods, 50 (2010) 6, 875-882, doi:10.2355/isijinternational.50.875

${ }^{15}$ L. P. Karjalainen, J. J. Jonas, Softening and flow stress behaviour of $\mathrm{Nb}$ microalloyed steels during hot rolling simulation, ISIJ International, 35 (1995) 12, 1523-1531, doi:10.2355/isijinternational.35. 1523

${ }^{16}$ H. Buken, E. Kozeschnik, A model for static recrystallization with simultaneous precipitation and solute drag, Metallurgical and Materials Transactions A, 48A (2017), 2812-2818, doi:10.1007/s11661016-3524-5

${ }^{17}$ J. Burja, M. Koležnik, Š. Župerl, G. Klančnik, Nitrogen and nitride non-metallic inclusions in steel, Materiali in tehnologije, 53 (2019) 6, 919-928, doi:10.17222/mit.2019.247

${ }^{18}$ L. Bäcke, Modeling of the effect of solute drag on recovery and recrystallization during hot deformation of $\mathrm{Nb}$ microalloyed steels, ISIJ International, 50 (2010) 2, 239-247, doi:10.2355/isijinternational.50.239

${ }^{19}$ S. Vervynckt, K. Verbeken, P. Thibaux, M. Thibaux, M. Liebeherr, Y. Houbaert, Austenite recrystallization-precipitation interaction in niobium microalloyed steels, SIJ International, 49 (2009) 6, 911-920, doi:10.2355/isijinternational.49.911

${ }^{20}$ P. Gong, E. J. Palmiere, W. M. Rainforth, Characterisation of strain-induced precipitation behaviour in microalloyed steels during thermomechanical controlled processing, Materials Characterization, 124 (2017), 83-89, doi:10.1016/j.matchar.2016.12.009

${ }^{21}$ A. Abdollah-Zedeh, D. P. Dunne, Effect of $\mathrm{Nb}$ on recrystallization after hot deformation in austenitic Fe-Ni-C, ISIJ International, 43 (2003) 8, 1213-1218, doi:10.2355/isijinternational.43.1213
${ }^{22}$ R. Barbosa, F. Boratto, S. Yue, J. J. Jonas, The influence of chemical composition on the recrystallisation behaviour of microalloyed steels, Proceedings from an International Symposium on Processing, Microstructure and Properties of HSLA Steels, Pittsburgh, 1988, 51-61.

${ }^{23}$ R. B. Sims, The calculation of roll force and torque in hot rolling mills, Proceedings of the Institution of Mechanical Engineers, 1954, 191-200, doi:10.1243/PIME_PROC_1954_168_023_02

${ }^{24}$ F. Zhang, Y. Zhao, J. Shao, Rolling force prediction in heavy plate rolling based on uniform differential neural network, Journal of Control Science and Engineering, (2016) 9, 1-9, doi:10.1155/2016/ 6473137

${ }^{25}$ K. J. Irvine, F. B. Pickering, T. Gladman, Grain-refined C-Mn steels. Journal of Iron and Steel Institute, 205 (1967) 2, 161-182

${ }^{26}$ EN 10025-6:2019 - Hot rolled products of structural steels - Part 6: Technical delivery conditions for flat products of high strength structural steels in the quenched and tempered condition

${ }^{27}$ EN ISO 6892-1:2020 - Metallic materials - Tensile testing - Part 1: Method of test at room temperature

${ }^{28}$ EN ISO 148-1:2016 - Metallic materials - Charpy pendulum impact test - Part 1: Test method

${ }^{29}$ A. Saastamoinen, A. Kaijalainen, D. Porter, P. Suikkanen, J. R. Yang, Y. T. Tsai, The effect of finish rolling temperature and tempering on the microstructure, mechanical properties and dislocation density of direct-quenched steel, Materials Characterization, 139 (2018), 1-10, doi:10.1016/j.matchar.2018.02.026

${ }^{30} \mathrm{~S}$. Morito, H. Yoshida, T. Maki, X. Huang, Effect of block size on the strength of lath martensite in low carbon steels, Materials Science and Engineering A, 438 (2006), 237-240, doi:10.1016/j.msea.2005. 12.048

${ }^{31}$ J. W. Morris, Comments on the microstructure and properties of ultrafine grained steel, ISIJ International, 48 (2008), 8, 1063-1070, doi:10.2355/isijinternational.48.1063

${ }^{32}$ B. Lopez, M. Rodriguez-Ibabe, Recrystallisation and grain growth in hot working of steels, Microstructure evolution in metal forming processes, Woodhead Publishing, (2012), 67-113 